\title{
The increased compression strength of an epoxy resin with the addition of heat-treated natural nano-structured diatom frustules
}

\author{
Doğuş Zeren' and Mustafa Güden²
}

\begin{abstract}
Natural diatom frustules composing nanometer size silica particles were heat-treated at temperatures between 600 and $1200^{\circ} \mathrm{C}$ for $2 \mathrm{~h}$ and used as filler/reinforcing agent $(15 \mathrm{wt} \%)$ in an epoxy resin. The opal structure of as-received natural diatom frustules was transformed into cristobalite after the heat-treatment above $900^{\circ} \mathrm{C}$. The epoxy resin test samples reinforced with heat-treated and as-received frustules and neat epoxy test samples were compression tested at the quasi-static strain rate of $7 \times 10^{-3} \mathrm{~s}^{-1}$. The results showed that the inclusion of the frustules heat-treated at $1000^{\circ} \mathrm{C}$ increased the compressive yield strength of the resin by $50 \%$, while the addition of the diatom frustules heat-treated above and below $1000^{\circ} \mathrm{C}$ and the as-received frustules increased the strength by $\sim 25 \%$ and $16 \%$, respectively. The heat treatment above $1000^{\circ} \mathrm{C}$ decreased the surface area of the frustules from $8.23 \mathrm{~m}^{2} \mathrm{~g}^{-1}$ to $3.46 \mathrm{~m}^{2} \mathrm{~g}^{-1}$. The cristobalite grains of the frustules heat-treated at $1000^{\circ} \mathrm{C}$ was smaller than $100 \mathrm{~nm}$, while the grain size increased to $\sim 500 \mathrm{~nm}$ at $1200^{\circ} \mathrm{C}$. The increased compressive stresses of the resin at the specific heat treatment temperature $\left(1000^{\circ} \mathrm{C}\right)$ were ascribed to nano size crystalline cristobalite grains. The relatively lower compressive stresses of the epoxy resin filled with frustules heat-treated above $1000^{\circ} \mathrm{C}$ were attributed to the micro-cracking of the frustules that might be resulted from higher density of the cristobalite than that of the opal and accompanying reduction of the surface area and the surface pore sizes that might impair the resin-frustule interlocking and intrusion.
\end{abstract}

\section{Keywords}

Polymeric composites, deformation and fracture, diatomite, frustules, compression

\section{Introduction}

Diatoms are the single-celled algae inhabited aquatic environments. ${ }^{1,2}$ The diatom cell is protected by a silicified shell of frustules, composed of $\sim 40 \mathrm{~nm}$ silica particles $^{3}$ and an organic layer of proteins. ${ }^{4}$ The structure is considered as an example to the natural composite material systems comprising a porous strong of frustules and very soft surrounding organic matrix. The frustules encompass regularly arrayed pores, ridges and protuberance, displaying genetically constructed three dimensional species specific ornamented intricate structure. Their sizes range $1-500 \mu \mathrm{m}$ and the pore sizes $10-200 \mathrm{~nm} .{ }^{5,6}$ When the diatom cells die, the shells are collected on the ocean floor, forming a cheap lightweight mineral source known as diatomite or diatomaceous earth. The diatomite, following a milling and in some cases a calcination process, is primarily used as filtering material and secondarily as filler for plastics and insulating material. As naturally forming material, the frustules have many potentials for diverse engineering applications including the templates or scaffolds for three-dimensional complex micro-scale polymeric, metallic and ceramic structures, ${ }^{5,7-9}$ gasselective metal film membranes and pin-point drug delivery (magnetized frustules). ${ }^{10}$ The mechanical

\footnotetext{
'Department of Materials Science and Engineering, Izmir Institute of Technology, Turkey

${ }^{2}$ Department of Mechanical Engineering, Izmir Institute of Technology, Turkey

Corresponding author:

Mustafa Güden, Department of Mechanical Engineering, Izmir Institute of Technology, Urla, Izmir 35430, Turkey.

Email: mustafaguden@iyte.edu.tr
} 
properties of individual diatom frustules have taken considerably interests in recent years and have shown to depend on the locations of measurements, resulting from the different stages of bio-mineralization process. ${ }^{11-15}$ The elastic modulus of diatom Navicula pelliclosa varied between 7 and $100 \mathrm{GPa}$ depending on the location of the measurements taken. ${ }^{13}$ The variations in the mechanical properties are related to the different stages of the bio-mineralization process of diatom frustule. The hierarchical arrangements of silica nanostructured natural materials including diatom frustules have numerically shown to reduce the stress intensity around a crack tip and made its composite structure less sensitive to the flaws by the combining action of the strain transfer of the soft matrix (organic layer) and stress transfer to the hard phase. ${ }^{12}$ It was shown through molecular dynamics simulations that the hierarchical structure of the nanostructure in diatom frustules resulted in deformable, strong, and tough material by the concurrent mechanisms of shearing and crack arrest. ${ }^{11}$ These two mechanisms are important in constructing composite structures with enhanced toughness properties. Figures 1(a) and (d) show the Scanning Electron Microscope (SEM) pictures of centric and long tube types of fossil diatom frustules, which is observed on the fracture surface of a clastic sedimentary rock obtained form Çeşme/İzmir province of Turkey. The magnified pictures of the cracks marked as b and c in Figure 1(a) are sequentially shown in Figures 1(b) and (c). The ductile fracture nature of the frustules in the form of elongated pores shown in these figures is likely to occur as a result of shearing of nano size silica particles. A similar shearing type fracture is also seen on the long tube diatom frustule at the locations marked with the letter of e in Figure 1(d) and shown in Figure 1(e) by the arrows. The action of the surface pores as the crack arrester is also detected and shown in Figure 1(f).

The frustules have relatively high surface area, $11-22 \mathrm{~m}^{2} \mathrm{~g}^{-1,14,16}$ therefore a strong interlocking between resin and frustules, when used as a filler, is expected as a result of the intrusions of resins into and interior of surface pores. It was also shown that the sizes of the pores on the frustules were gradually enlarged by the HF-treatment without changing the chemical structure, ${ }^{17}$ allowing the tailoring of the resin intrusion through the pores and interior. The increased compressive modulus and yield strength of an epoxy resin filled with diatomite frustules at quasistatic and high strain rates were previously reported. ${ }^{18}$ The strengthening of resin was attributed to the strong interlocking between matrix and relatively strong frustules. The present study is a continuation of the previous studies $^{18,19}$ and focused on the effect of diatomite heat treatment on the compression stress-strain behavior of resin at quasi-static strain rates. The heat treatment was performed between 600 and $1200^{\circ} \mathrm{C}$ for $2 \mathrm{~h}$. The effects of heat treatment on the surface area of frustules and the compression mechanical behavior of frustule filled resin were determined. It was shown that at a certain
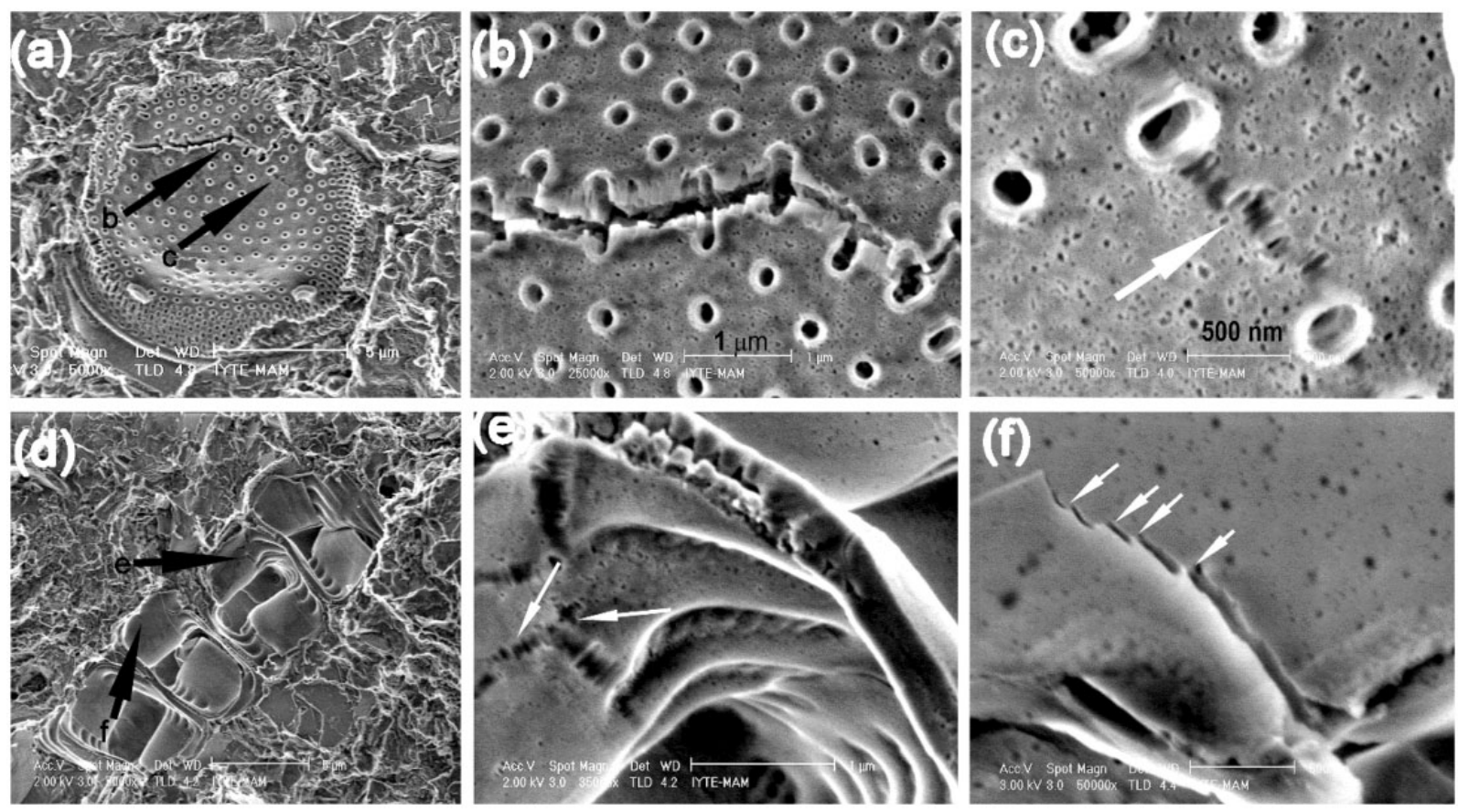

Figure I. The SEM pictures of the sediment rock contained fossil diatom frustules: $(a, b, c)$ centric; $(d, e, f)$ long-tube-shaped frustules. 
heat treatment temperature the diatom frustule addition maximized the matrix strengthening. This was attributed to the change of the crystal structure and development of the nano crystalline grains of the frustules. The results of present work can also be used to maximize the strength of the diatomaceous earth material when it is used both as filtering and filler material.

\section{Experimental}

The particle size distribution of frustules was determined in water with ultra-sonication using a Mastersizer Particle Size Analyzer. The crystallographic structure of diatom frustules was determined using a Philips X'Pert Pro X-Ray Diffraction (XRD) device $\left(\mathrm{Cu}-\mathrm{K} \alpha\right.$ radiation, $\lambda=1.54 \mathrm{~A}^{\circ}, 40 \mathrm{kV}$ and 5-80 $)$. The elemental composition was determined using a Spectro IQ II X-Ray Fluorescence (XRF) device. The chemical bonding of frustules was determined with Perkin Elmer Fourier Transform Infrared (FTIR) System Spectrum BX Spectroscopy. The morphological properties and surface topography of frustules and frustules filled composite samples were investigated using an FEI Quanta 205 FEG SEM in secondary and back scattered electron modes. The Brunauer-Emmett-Teller (BET) surface area of heat treated frustules was determined using a Micromeritics Gemini V device.

The heat treatment of frustules was performed in a box furnace between 600 and $1200^{\circ} \mathrm{C}$ with $100^{\circ} \mathrm{C}$ intervals for $2 \mathrm{~h}$. The frustules were inserted into the furnace at room temperature and heated to the heat treatment temperature within $10 \mathrm{~min}$. To prepare filled epoxy samples, as-received and heat-treated natural diatomite frustules (Alfa Aesar, Johnson Matthey Co., England) were first mixed with a Bispenol-A type epoxy resin using a mechanical disperser (Ultra-Turrax $\mathrm{T}$ 25, IKA $^{\circledR}$ Werke $\mathrm{GmbH} \& \mathrm{Co}$ ) at $20,000 \mathrm{rpm}$ for $5 \mathrm{~min}$. After mixing, the mixture was kept under vacuum to remove trapped gas bubbles; then, a hardener (Grandmer VN-111, Süper Selva Şti, İzmir, Turkey) with an amount $2.5 \%$ of epoxy resin was added. The mixture was stirred gently upon the addition of hardener and poured into a silicon mold $\left(4 \times 4 \times 1 \mathrm{~cm}^{3}\right)$. The resin-hardener mixture with $15 \mathrm{wt} \%$ frustules was kept in the mold at room temperature for $24 \mathrm{~h}$ and then cured at $110^{\circ} \mathrm{C}$ for $5 \mathrm{~h}$. The compression test samples were core-drilled from the molded composite plates after flatting the surfaces by grinding. The test samples were $9.80 \mathrm{~mm}$ in diameter and $12 \mathrm{~mm}$ in length, with an aspect ratio of 1.22 (Figure 2(a)). For comparison, neat epoxy samples were also prepared following a similar procedure outlined above. The cross-sectional micrograph of polished surface of a test sample (normal
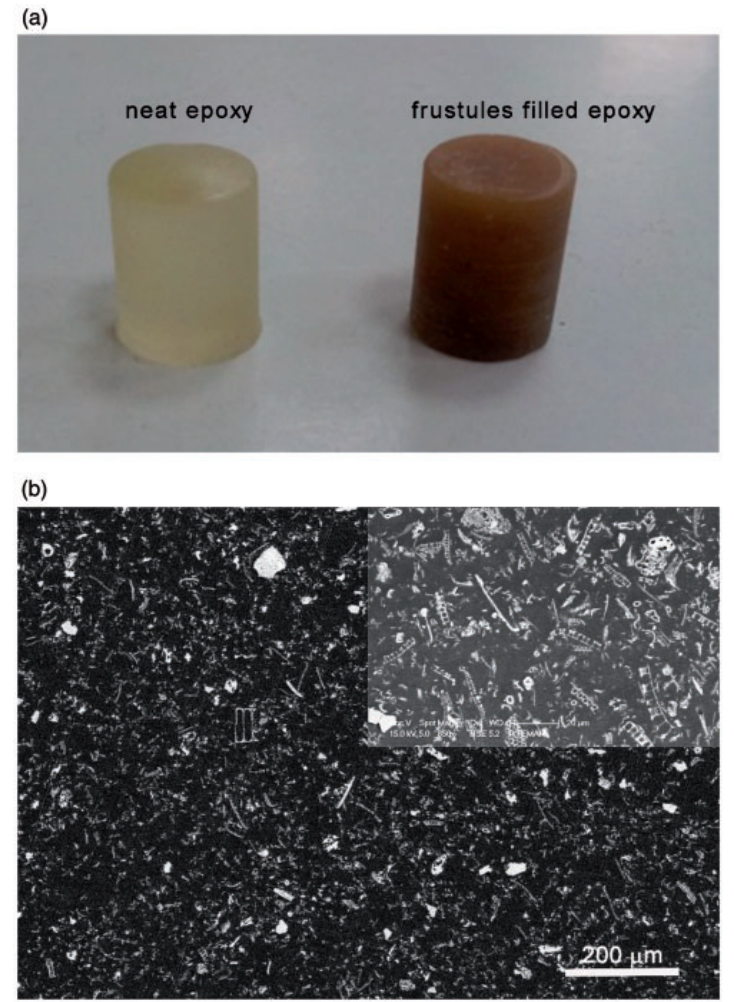

Figure 2. (a) Neat epoxy and frustules filled epoxy core drilled compression test samples and (b) SEM images of the polished surface of as received frustules filled epoxy.

to the compression axis) seen in Figure 2(b) indicates that the frustules are homogeneously distributed in the epoxy matrix. The long axis of the frustules are planarrandom distributed on the plane normal to the loading axis as depicted in a higher magnification SEM micrograph shown in the inset of Figure 2(b). Compression tests were performed in a $300 \mathrm{kN}$ load-cell Shimadzu AGI universal test machine using self-aligned standard compression test platens at a crosshead speed of $5 \mathrm{~mm}$ $\min ^{-1}$, corresponding to a quasi-static strain rate of $7 \times 10^{-3} \mathrm{~s}^{-1}$. Before the tests, the surfaces of the test platens were lubricated using a molybdenum-based lubricant. The displacement of the sample were recorded using a video extensometer directly connected to the testing machine.

\section{Results and discussion}

The powder size analysis showed that $90 \%$ and $10 \%$ of as-received frustules were smaller than $54.4 \mu \mathrm{m}$ and $3.9 \mu \mathrm{m}$, respectively, with a mean size of $16.8 \mu \mathrm{m}$. As-received diatomite powder is consisted of both centric type (radially symmetric, Figure 3(a)) and pennate type (bilaterally symmetric, Figure 3(b)) of frustules. The broken/crushed frustules seen in Figure 3(b) were 

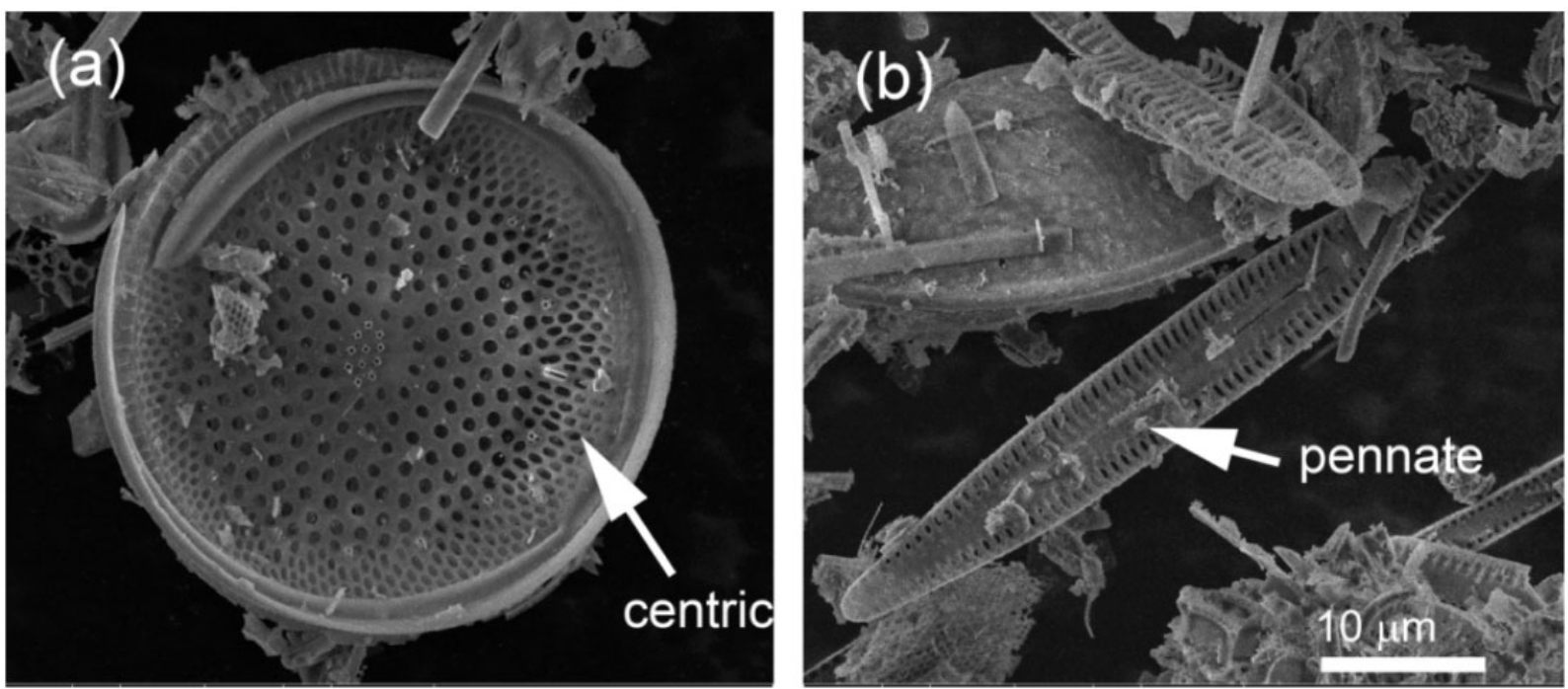

Figure 3. SEM images of as-received diatomaceous earth powder: (a) centric and (b) pennate diatom frustules.

resulted from the milling operation performed by the producer. The XRF analyses showed that the diatomite powder consisted of $90 \%$ of $\mathrm{SiO}_{2}, \% 5$ of $\mathrm{Al}_{2} \mathrm{O}_{3}, 1.5 \%$ of $\mathrm{Fe}_{2} \mathrm{O}_{3}, \% 1$ of $\mathrm{MgO}$, and $0.5 \%$ of $\mathrm{CaO}$. The color of diatomite powder changed gradually from gray to pink as the heat-treatment temperature increased from $600^{\circ} \mathrm{C}$ to $1200^{\circ} \mathrm{C}$.

The XRD spectra of as-received and heat-treated diatomite powder as function of temperature are shown in Figure 4(a). The broad XRD pattern of asreceived diatomite powder $\left(25^{\circ} \mathrm{C}\right)$ reveals amorphous opal structure as the major phase and quartz structure as the minor phase. ${ }^{20}$ The XRD patterns of heattreated diatomite powder between 600 and $900^{\circ} \mathrm{C}$ show no extra crystal peaks, exhibiting a similar crystal structure with the as-received diatomite powder. The transformation of amorphous silica to cristobalite low (Ref. 76-0940) starts at $\sim 1000^{\circ} \mathrm{C}$ (Figure $4(\mathrm{a})$ ). The FTIR spectra of as-received and heat-treated diatomite powder are shown in Figure 4(b). The band detected at $1076-1100 \mathrm{~cm}^{-1}$ is assigned to $\mathrm{Si}-\mathrm{O}-\mathrm{Si}$ antisymmetric stretching mode. The adsorption band at $750-850 \mathrm{~cm}^{-1}$ represents the symmetric $\mathrm{Si}-\mathrm{O}-\mathrm{Si}$ stretching mode. The wave numbers of 618 and $450 \mathrm{~cm}^{-1}$ symbolize the bands characteristic of the $\mathrm{Si}-\mathrm{O}-\mathrm{Si}$ framework. A new band at $618 \mathrm{~cm}^{-1}$ seen in the spectrum of frustule treated at $1200^{\circ} \mathrm{C}$ demonstrates the transforms into cristobalite phase. ${ }^{21}$ Opal to cristobalite transformation was previously reported above $1000^{\circ} \mathrm{C}$ and the applied heat treatment above this temperature increased the intensity of cristobalite phase peaks until about $1400^{\circ} \mathrm{C} .{ }^{22} \mathrm{~A}$ similar trend is also
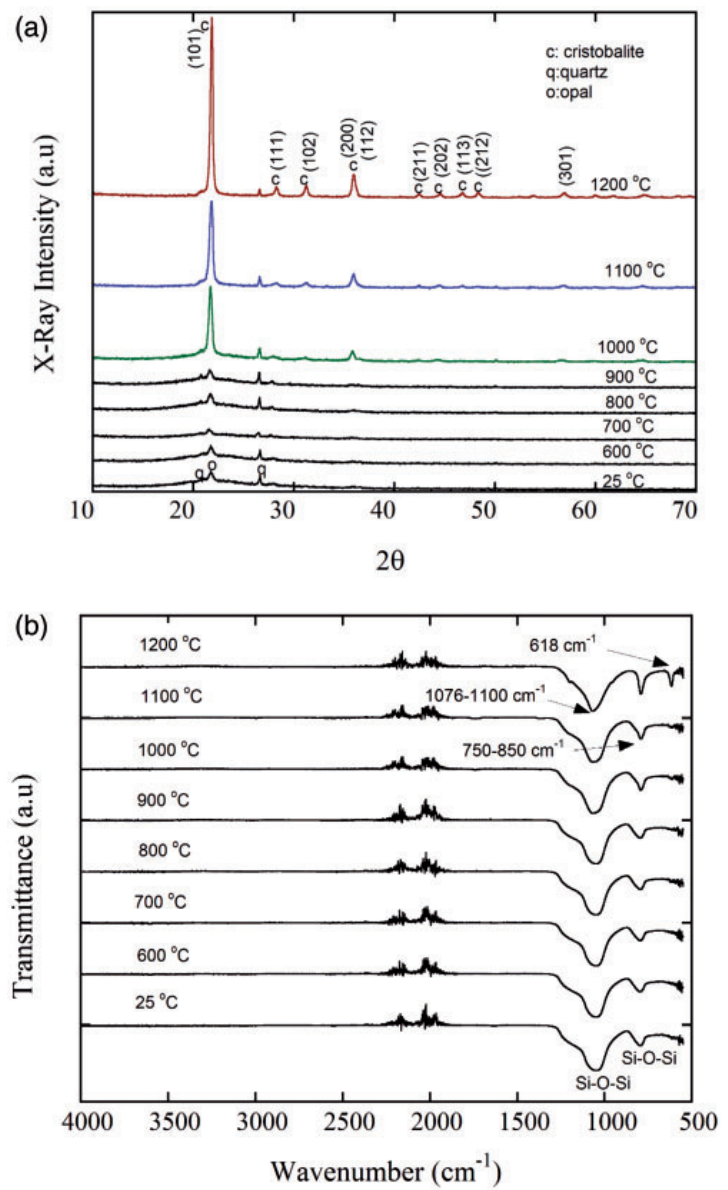

Figure 4. (a) XRD and (b) FTIR spectra of the as-received and heat-treated diatomite frustules. 

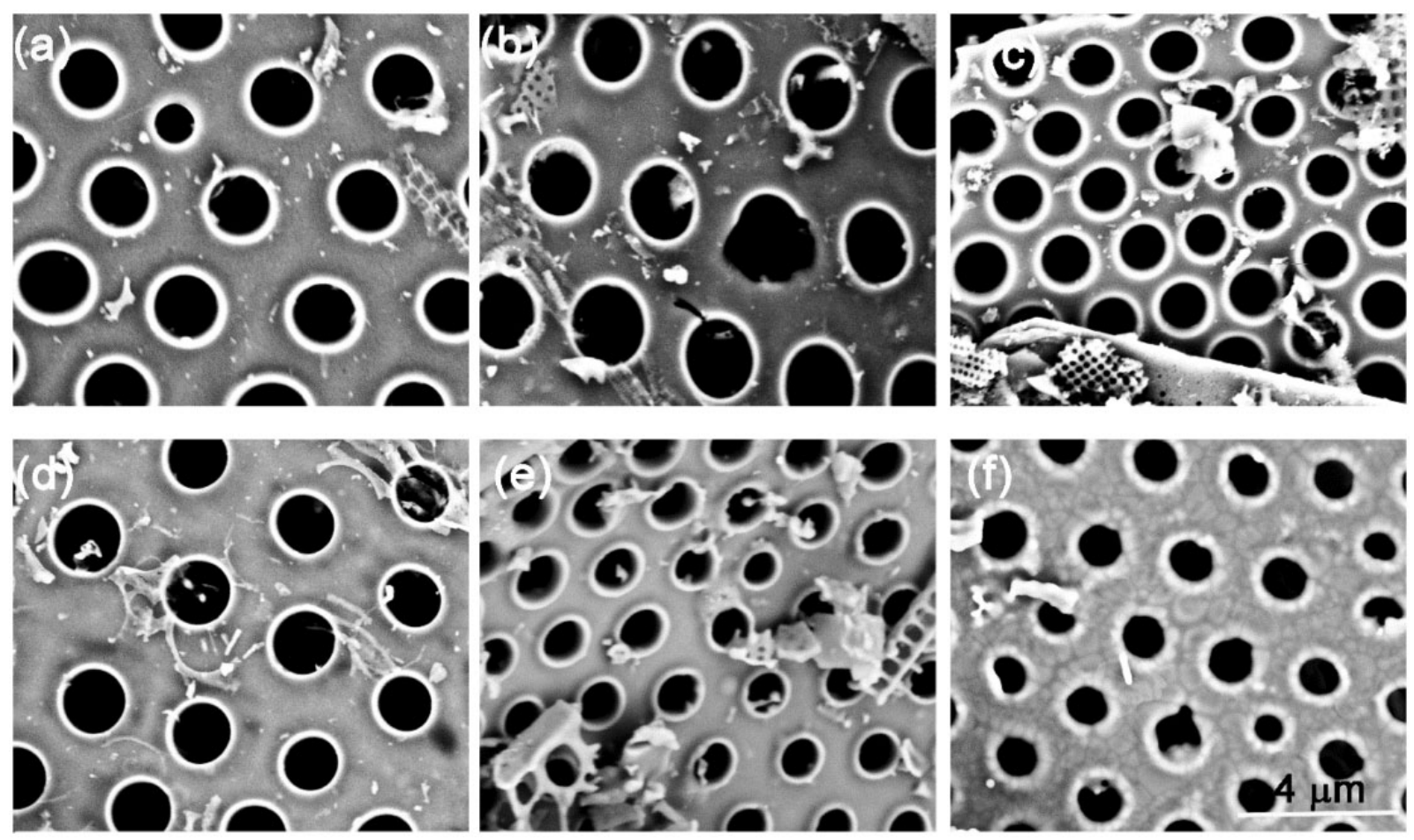

Figure 5. SEM images of frustules surfaces (a) as-received and heat-treated at (b) $800^{\circ} \mathrm{C}$, (c) $900^{\circ} \mathrm{C},(\mathrm{d}) 1000^{\circ} \mathrm{C},(e) 1100^{\circ} \mathrm{C}$, and (f) $1200^{\circ} \mathrm{C}$.

observed in the present study: the intensity of cristobalite peaks increases when the heat treatment temperature increases from $1000^{\circ} \mathrm{C}$ to $1200^{\circ} \mathrm{C}$. The same transformation temperature was also reported previously for the sintered diatomite powder compacts and the direct transformation of opal to cristobalite was attributed to the presence of mineralizers promoting cristobalite crystallization. $^{23}$

The SEM micrographs of the frustules heat-treated at different temperatures are shown in Figures 5(a)-(f). The similar type of frustules are selected for the microscopic observations to accurately differentiate the effect of heat treatment temperature on the surface morphologies of the frustules. No significant effect of heat treatment temperature on the surface morphologies of frustules are seen in the powders heat-treated at 800 , 900 , and $1000^{\circ} \mathrm{C}$ (Figure 5(b)-(d)), while the surface pores tend to close at higher heat treatment temperatures, particularly at $1200^{\circ} \mathrm{C}$ (Figure 5(e) and (f)) . Figures 6(a) and (b) show the micrographs of the as-received frustule surface pores and a magnified micrograph taken in between the pores, respectively. A nano size porous surface is clearly seen in Figure 6(b) in the as-received frustules. The effects of heat treatment are clearly seen in Figures 6(c) and (d), the surface pore edges of the frustules flatten out (Figure 6(c)) and nano size porous surface morphology in between the pores almost disappears (Figure 6(d)). The cristobalite grain boundaries are also visible in Figure 6(d), resulting from the thermal etching of the grains with the heat-treatment. To reveal the cristobalite crystals, the heat-treated frustules were aged with a $10 \mathrm{~N}$ hydrofluoric acid (HF)-solution for $1 \mathrm{~min}$ and then washed with distilled water. The acid-aged frustule surfaces of the same type but heat-treated at different temperatures were microscopically observed in SEM. Figures 7(a)-(f) show the SEM micrographs of acid-aged as-received and heat-treated frustules surfaces. The SEM micrographs of as-received and heat-treated frustules between 600 and $900^{\circ} \mathrm{C}$ show almost no difference in surface structure, revealing the same amorphous opal structure. However, small grains of cristobalite phase, $50-100 \mathrm{~nm}$, are seen in the microstructure of the frustules heat-treated at $1000^{\circ} \mathrm{C}$, white regions in Figure 7(d). The magnified SEM micrograph of these grains is shown in Figure 8(a). In this micrograph, the black regions correspond to the dissolved amorphous phase/remnant surface pores. The cristobalite grain size and amount however significantly increase when the heat treatment temperature increases to 1100 and $1200^{\circ} \mathrm{C}$ (Figures 7(e) and (f)). The cristobalite grain size reaches $\sim 500 \mathrm{~nm}$ and the transformation is almost completed when the heat-treatment temperature increases to $1200^{\circ} \mathrm{C}$ as shown in Figure 8(b).

The compression stress-strain curves of neat epoxy and filled epoxy are shown in Figure 9 together. 

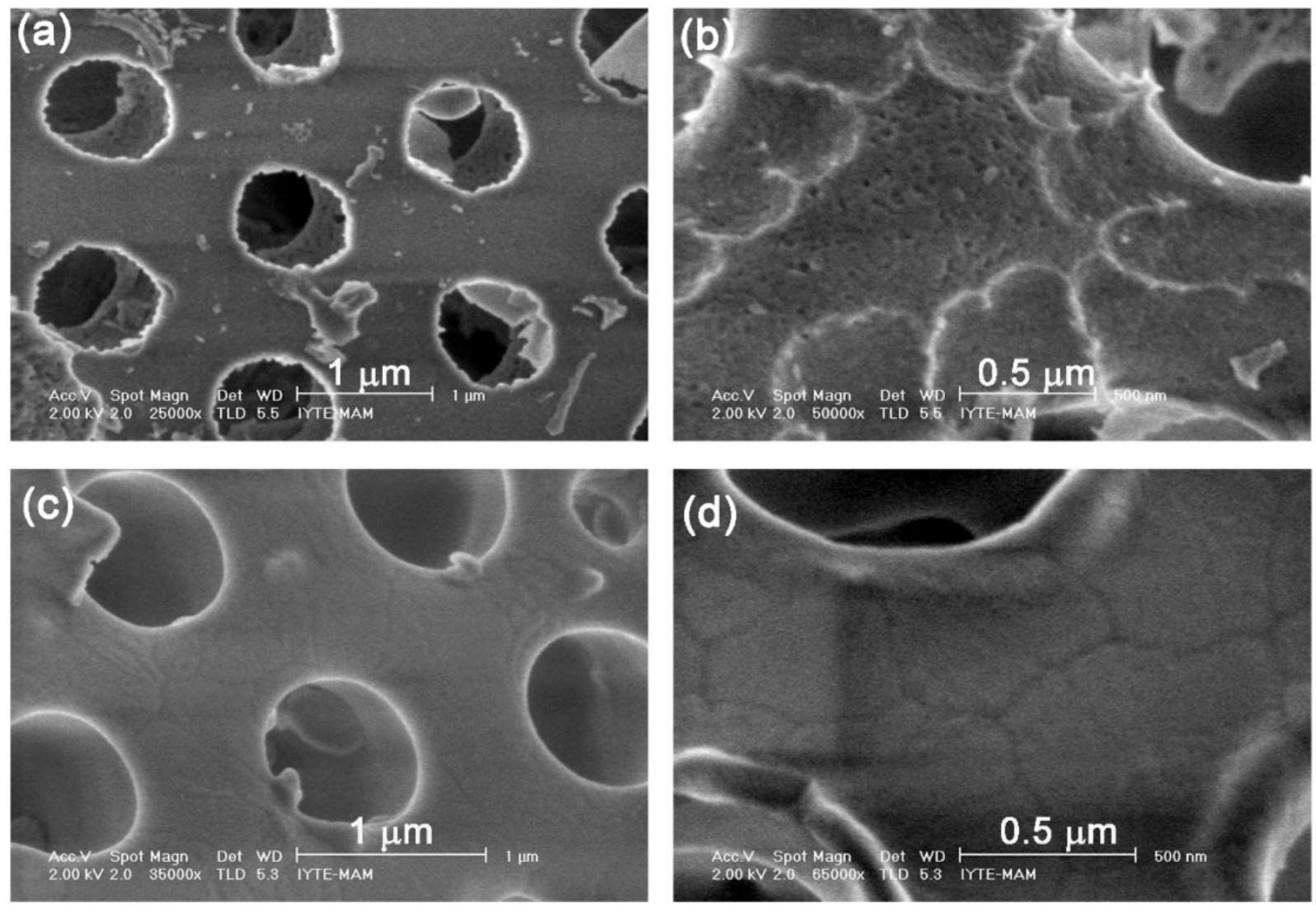

Figure 6. SEM images of frustules surfaces (a) and (b) as-received and (c) and (d) heat-treated at $1200^{\circ} \mathrm{C}$.
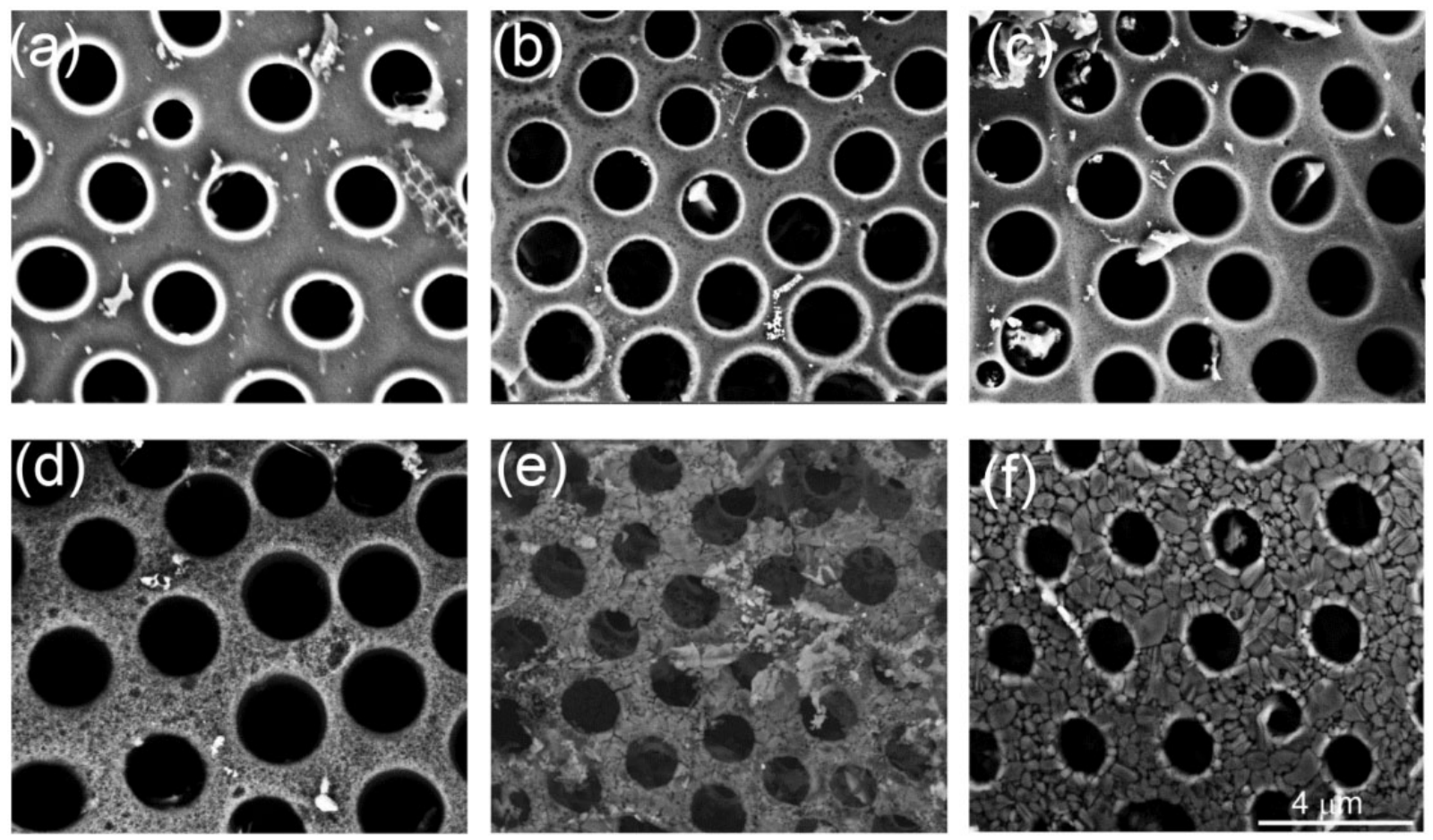

Figure 7. SEM images of HF-etched frustules surfaces (a) as-received and heat-treated at (b) $600^{\circ} \mathrm{C}$, (c) $900^{\circ} \mathrm{C}$, (d) $1000^{\circ} \mathrm{C}$, (e) $1100^{\circ} \mathrm{C}$, and (f) $1200^{\circ} \mathrm{C}$. 

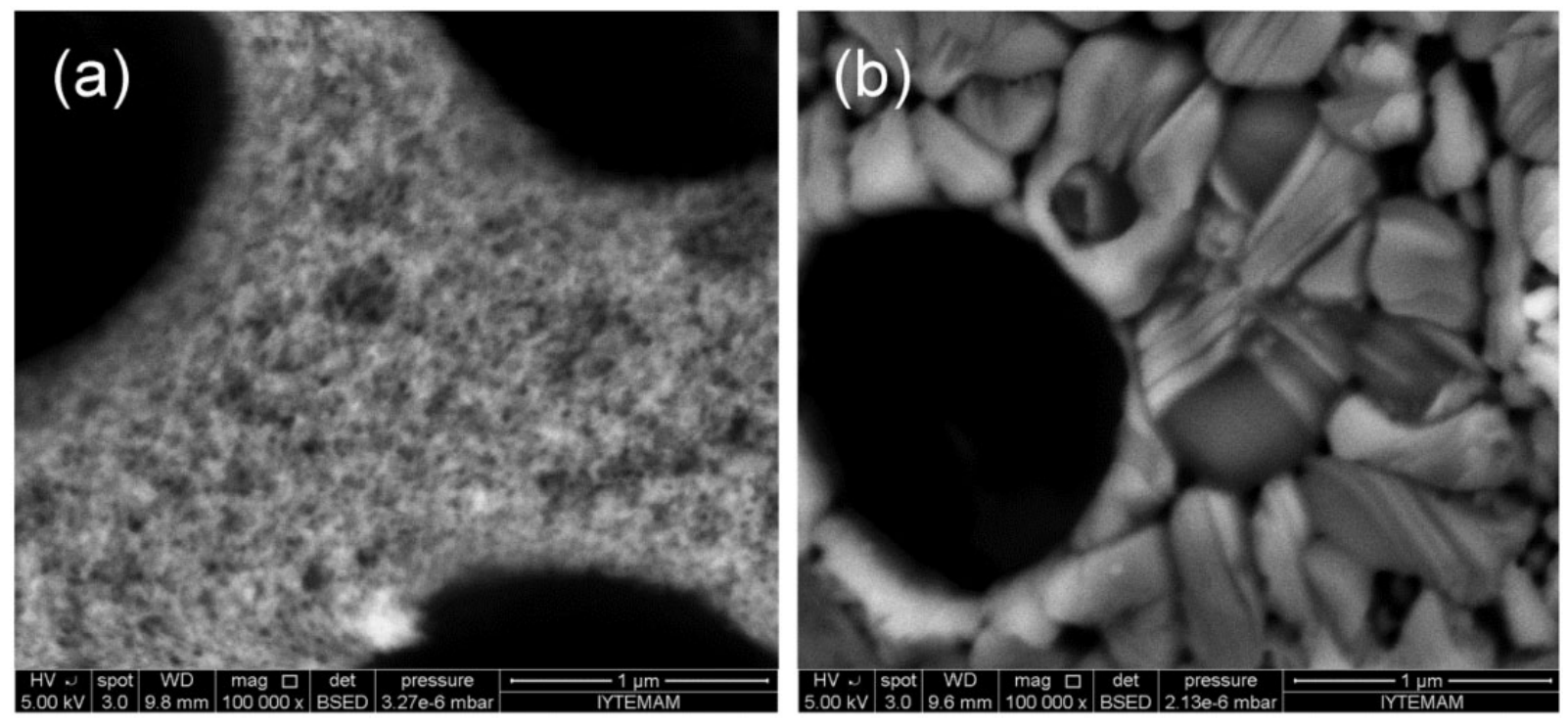

Figure 8. SEM surface images of HF-etched frustules heat-treated at (a) $1000^{\circ} \mathrm{C}$ and (b) $1200^{\circ} \mathrm{C}$.

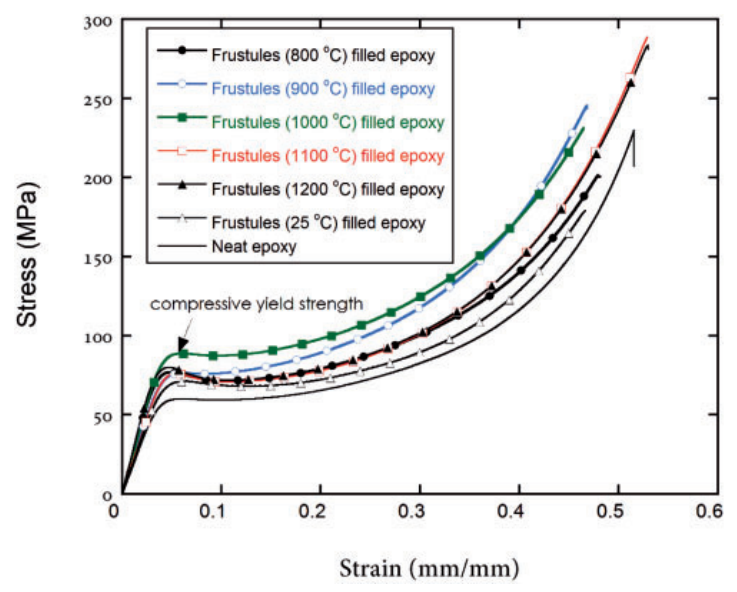

Figure 9. Compression stress-strain curves of as-received and heat-treated frustules filled epoxy and neat epoxy.

The tests (at least three tests) were found repeatable; therefore, only representative single test is shown for each group of sample in Figure 9. Initially, the deformation is noted to be elastic; thereafter, the compression yield stress is reached at a strain of 0.047 both in neat and filled epoxy samples (Figure 9). The addition of asreceived frustules increases the compressive yield strength of epoxy from $\sim 60 \mathrm{MPa}$ (neat epoxy) to $\sim 70 \mathrm{MPa}$, corresponding to $16 \%$ increase in the compressive yield strength as seen in Figure 9. The addition of the frustules heat-treated at 800 and $900^{\circ} \mathrm{C}$ increases the compressive yield strength, sequentially to 74 and $76 \mathrm{MPa}(\sim 25 \%$ increase). The addition of the frustules heat-treated at $1000^{\circ} \mathrm{C}$ increases both the compressive yield strength and post compression stresses of the

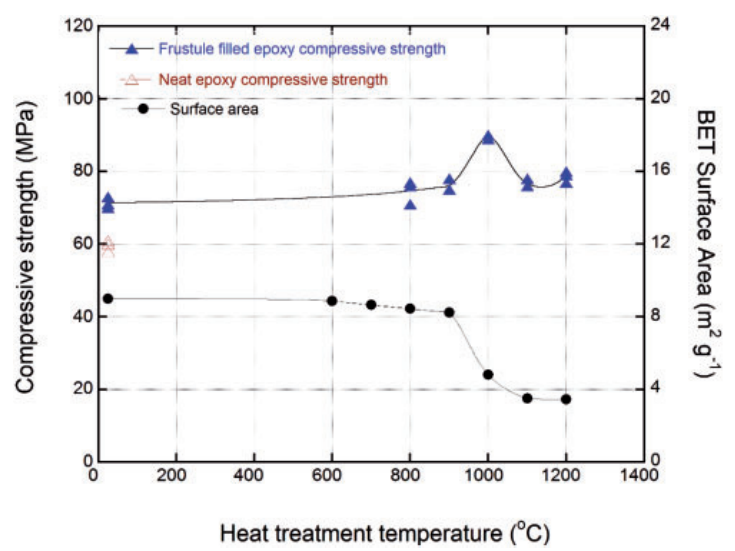

Figure 10. The variations of (a) the compressive yield strength of as-received and heat-treated frustules filled epoxy and neat epoxy and (b) the BET surface area of the frustules with heat treatment temperature.

epoxy matrix. The compressive yield strength increases from $60 \mathrm{MPa}$ in neat resin to $90 \mathrm{MPa}$ with the addition of the frustules heat-treated at $1000^{\circ} \mathrm{C}$, corresponding to $50 \%$ increase in the compressive yield strength. The heat treatment of frustules at 1100 and $1200^{\circ} \mathrm{C}$, however decreases the compressive yield strength to $75 \mathrm{MPa}$. These results indicate that the maximum strengthening of epoxy resin occurs at the specific heat-treatment temperature of $1000^{\circ} \mathrm{C}$, while the heat treatment below and above this temperature results in relative reductions in the compressive yield strength. As-received diatom powder has a surface area of $8.9 \mathrm{~cm}^{2} \mathrm{~g}^{-1}$ and the surface area decreases to $8.23 \mathrm{~cm}^{2} \mathrm{~g}^{-1}$ when the heat treatment temperature increases to $900^{\circ} \mathrm{C}$ (Figure 10). A significant reduction in the surface area however 

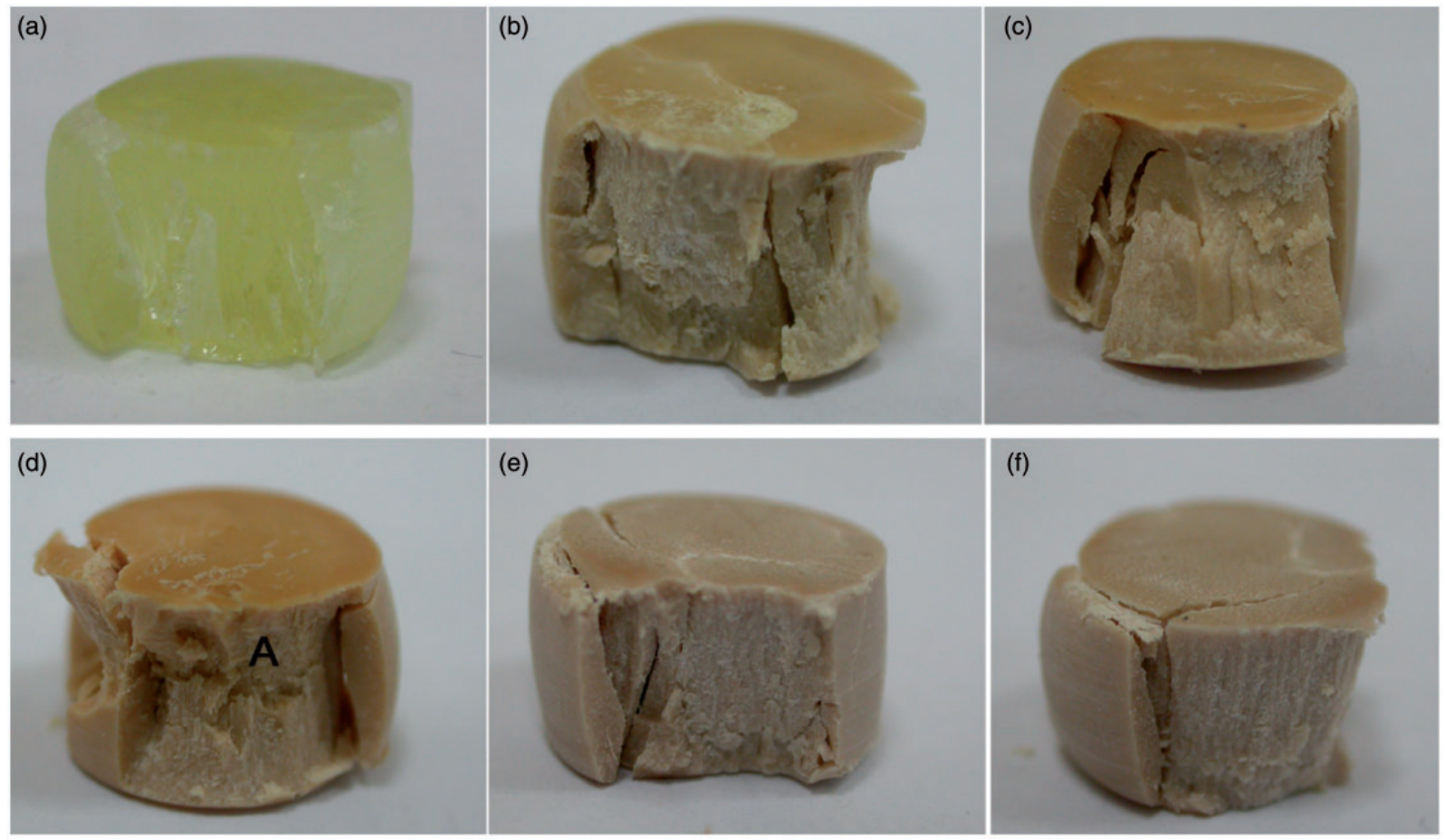

(e)

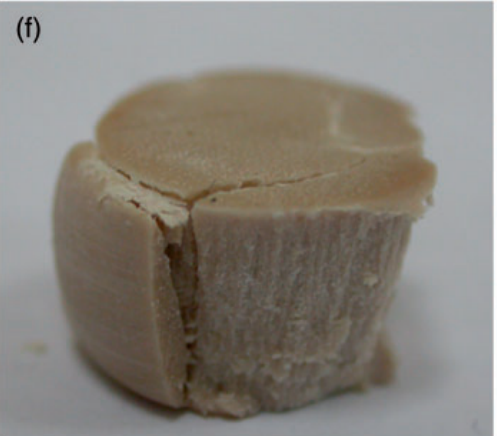

Figure II. The pictures of frustule filled epoxy samples after compression test (a) neat resin and epoxy filled with the frustules heat-treated at (b) $800^{\circ} \mathrm{C}$, (c) $900^{\circ} \mathrm{C}$, (d) $1000^{\circ} \mathrm{C}$, (e) $1100^{\circ} \mathrm{C}$, and (f) $1200^{\circ} \mathrm{C}$.

occurs after about $900^{\circ} \mathrm{C}$. The surface area decreases to $4.79 \mathrm{~cm}^{2} \mathrm{~g}^{-1}$ when the heat treatment temperature increases to $1000^{\circ} \mathrm{C}$ and to $3.46 \mathrm{~cm}^{2} \mathrm{~g}^{-1}$ when the temperature increases to 1100 and $1200^{\circ} \mathrm{C}$. The reduced surface area of the diatom frustules with the heat treatment was reported previously. ${ }^{24}$ The reduced surface area is expected to adversely affect the resin-frustule interlocking. The reduced compressive yield strength of the filled epoxy with the addition of frustules heattreated at 1100 and $1200^{\circ} \mathrm{C}$ is partly explained by the reduced frustules surface area, which impairs the frustule-resin interlocking. However, this phenomenon cannot explain the increased compressive yield strength of resins filled with the diatom frustules heat-treated at $1000^{\circ} \mathrm{C}$. In present study, the effect of diatomite heat treatment on the mechanical properties was investigated through compression tests normal to the planar random plane. The effect of diatomite frustule filling on the fracture stress and fracture strain can also be determined through tensile tests. ${ }^{19}$ This will be investigated in future.

The difference between the thermal expansion coefficients of opal and cristobalite may induce residual stresses when the frustules are cooled from the heat treatment temperature. The residual stresses may eventually lead to micro-cracking of the frustules, which will reduce the fracture strength of the frustules. ${ }^{23}$ However, the microscopic observations did not reveal any sign of the micro-cracking in the frustules heat-treated at 1000 and $1200^{\circ} \mathrm{C}$.
The pictures of the failed compression test samples of neat epoxy and frustules filled epoxy are shown in Figures 11(a)-(f). The combined effect of shear and axial splitting seems to lead to the fracture of all compression test samples except the sample filled with frustules heat-treated at $1000^{\circ} \mathrm{C}$, which shows shear dominated failure (Figure 11(d)). The SEM micrographs of the fracture surfaces of tested and fractured epoxy samples filled with the frustules heat-treated at $800,900,1000$, and $1100^{\circ} \mathrm{C}$ are sequentially shown in Figure 12(a)-(d). The SEM pictures were taken from the fractured surface at a location in between the middle and end of the sample along the loading axis (A in Figure 11(d)). The fracture surface micrographs of recovered diatomite filled samples shown in Figures 12(a)-(d) reveal the broken frustules, proving the effective loading and resin-intrusion of the frustules. The debonded and fractured frustules are clearly seen in Figures 12(a)-(c). It is also seen in the same figures that the epoxy intrudes efficiently to nano size surface and submicron size pores of the frustules. The intruded epoxy is pulled during fracture and the frustules show multiple fracture (Figures 12(a) and (b)). Two types of matrix pulling mechanisms are detected on the fracture surfaces. The first is the pulling of the resin intruded through the submicron size pores extending along the frustules section. The resin in the first mechanism fractures by forming a typical necked region (Figures 12(a)-(d)). The second is the pulling of the resin 

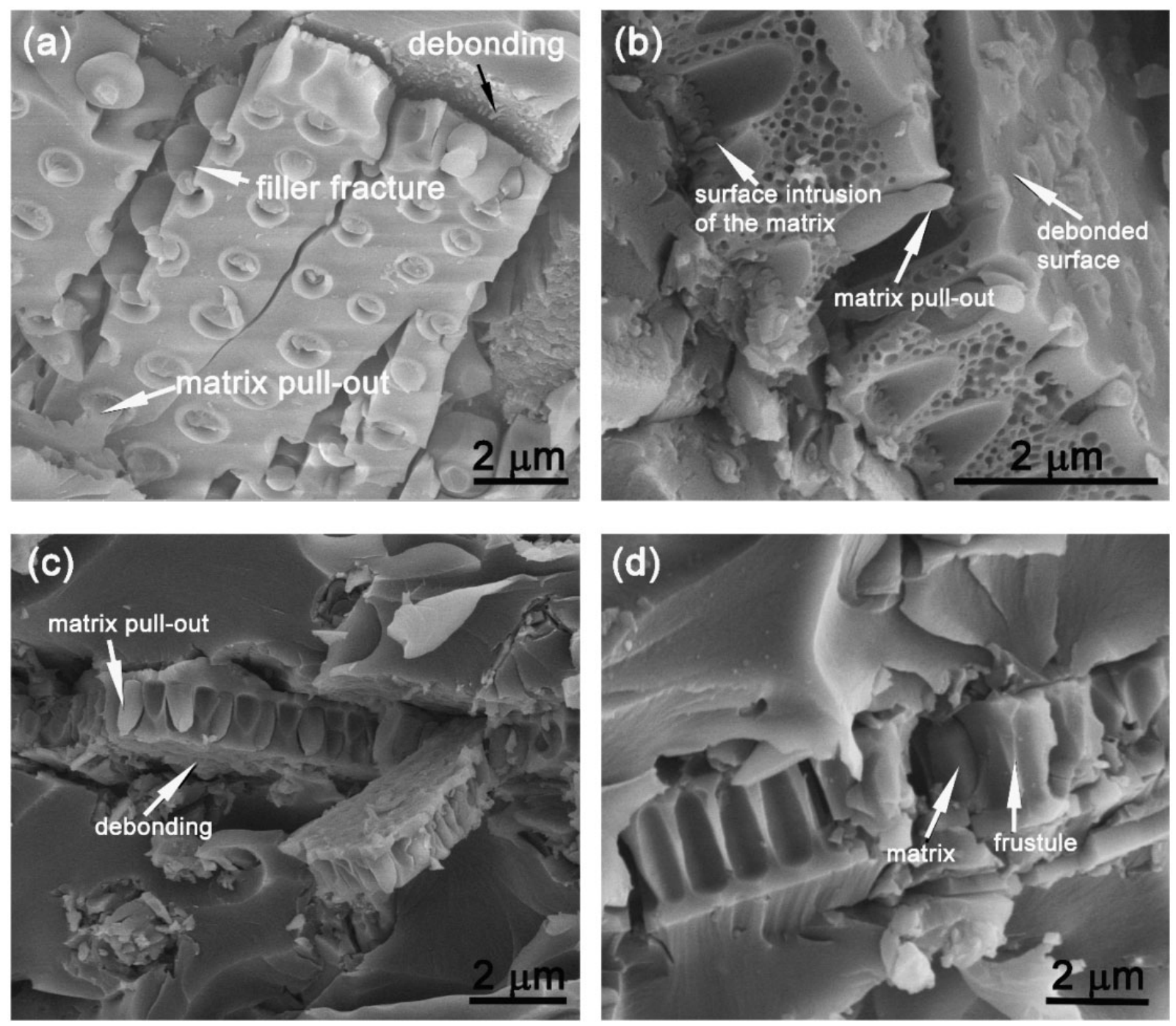

Figure 12. SEM images of the heat-treated fracture surfaces of frustules-filled epoxy: frustules heat treatments (a) $800^{\circ} \mathrm{C}$, (b) $900^{\circ} \mathrm{C}$, (c) $1000^{\circ} \mathrm{C}$, and (d) $1100^{\circ} \mathrm{C}$.

intruded to the nano size surface pores as seen in Figure 12(a) (marked with debonding) and in Figure 12(b) (marked with surface intrusion of the matrix). The surface pore intrusion of the matrix provides is expected to contribute to bonding to the matrix. Both mechanisms tend to increase the work of fracture of the resin.

Figures 13(a) and (b) show for comparison the general pictures of the fractured test samples filled with the frustules heat-treated at 800 and $1200^{\circ} \mathrm{C}$, respectively. The excessive fragmentation of the frustules on the fracture surface of the sample filled with the frustules heat-treated at $1200^{\circ} \mathrm{C}$ are shown in Figure 13(b). Partly due to the excessive reduction of the surface area and partially due to the closing the surface pores, the physical bonding between frustules and resin, the debonding between frustules and matrix is expected occur more easily in the samples filled with the frustules heat-treated at $1200^{\circ} \mathrm{C}$. This excessive fragmentation of the frustule on the fracture surface is likely to occur as a result of debonding of the frustules from the matrix and subsequent excessive crushing the frustules in between the mating fracture surfaces of the test sample. The excessive fragmentation may also be taken as a sign of micro cracking of the frustules. The stress transferred from resin to the frustule can lead to the brittle multiple crushing of the frustules at the locations of the micro cracks. It is noted that the cristobalite grains of the frustules heat-treated at $1000^{\circ} \mathrm{C}$ is smaller than $100 \mathrm{~nm}$, while it increases to $250-500 \mathrm{~nm}$ at $1200^{\circ} \mathrm{C}$ (Figure 5(b)). The effect of cristobalite grain size on the fracture strength of frustule is not clear and will be addressed in future studies. 

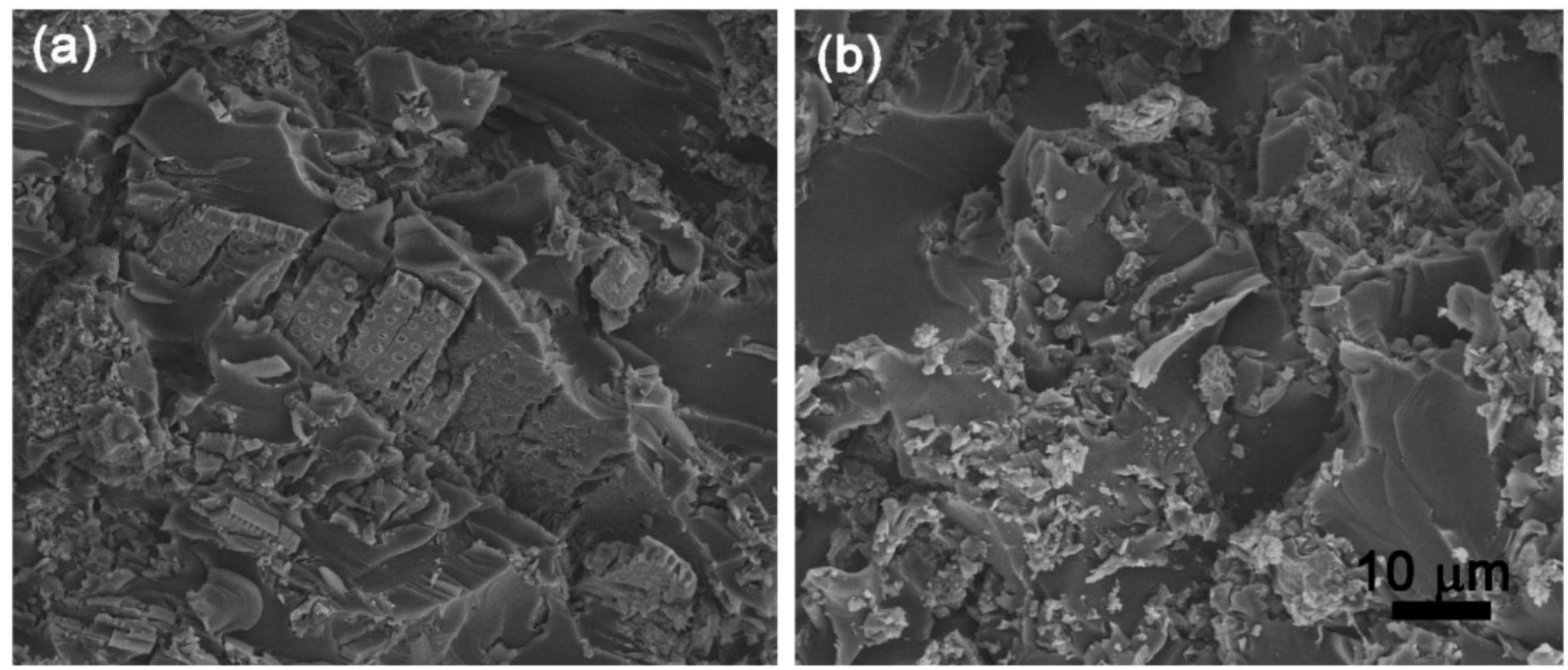

Figure 13. SEM images of the heat-treated fracture surfaces of frustules-filled epoxy: frustules heat treatments (a) $800^{\circ} \mathrm{C}$ and (b) $1200^{\circ} \mathrm{C}$.

The present work has shown that the strengthening can be maximized with the frustules filling the thermoset resins by applying a heat-treatment at a specific temperature. The strengthening may be as high as $50 \%$. The increased fracture strength also increases the energy absorption by considering a constant failure strain corresponding to the compressive strength. This work may also be extended to use frustules as filler in softer organic materials. In such a composite structure, the frustules strengthening and its contribution to the energy absorption and to the failure strain of the matrix might be more significant than those of the investigated resin.

\section{Conclusions}

The effect of heat-treated natural diatom frustules addition on the compression behavior of an epoxy resin was experimentally investigated. The XRD results showed that opal to cristobalite transformation started at $1000^{\circ} \mathrm{C}$. The frustule addition increased the compressive yield strength compared with neat epoxy. The increase in compressive yield strength was 16 and $25 \%$ with the addition of as-received frustule and heat-treated frustules except the addition of the frustules heat-treated at $1000^{\circ} \mathrm{C}$. The addition of the frustules heat-treated at $1000^{\circ} \mathrm{C}$ increased the compressive yield strength of the resin by $50 \%$. The heat treatment above $900^{\circ} \mathrm{C}$ decreased the surface area of the frustules from $8.23 \mathrm{~cm}^{2} \mathrm{~g}^{-1}$ to $3.46 \mathrm{~cm}^{2} \mathrm{~g}^{-1}$. The reduced surface area adversely affected the resin-frustule interlocking. As the density of cristobalite phase was greater than that of opal, the transformation might induce microcracking, reducing the strength of the frustules.
The tested samples filled with the frustules heat-treated at $1200^{\circ} \mathrm{C}$ indicated excessive frustules fragmentation on the fracture surface.

\section{Declaration of Conflicting Interests}

The author(s) declared no potential conflicts of interest with respect to the research, authorship, and/or publication of this article.

\section{Funding}

The author(s) received no financial support for the research, authorship, and/or publication of this article.

\section{References}

1. Round FE, Crawford RM and Mann DG. Diatoms: Biology and morphology of the genera. Cambridge: Cambridge University Press, 1990.

2. Gordon R and Drum RW. The chemical basis of diatom morphogenesis. Int Rev Cytol-Survey Cell Biol 1994; 150: 243-372.

3. Crawford SA, Higgins MJ, Mulvaney $P$, et al. Nanostructure of the diatom frustule as revealed by atomic force and scanning electron microscopy. J Phycol 2001; 37: 543-554.

4. Abramson L, Wirick S, Lee C, et al. The use of soft X-ray spectromicroscopy to investigate the distribution and composition of organic matter in a diatom frustule and a biomimetic analog. Deep-Sea Res Part II-Top Stud Oceanogr 2009; 56: 1369-1380.

5. Gaddis CS and Sandhage KH. Freestanding microscale 3D polymeric structures with biologically-derived shapes and nanoscale features. J Mater Res 2004; 19: 2541-2545.

6. Fuhrmann $\mathrm{T}$, Landwehr S, El Rharbi-Kucki M, et al. Diatoms as living photonic crystals. Appl Phys B-Lasers Opt 2004; 78: 257-260. 
7. Yu Y, Addai-Mensah J and Losic D. Synthesis of selfsupporting gold microstructures with three-dimensional morphologies by direct replication of diatom templates. Langmuir 2010; 26: 14068-14072.

8. Sandhage KH, Allan SM, Dickerson MB, et al. Merging biological self-assembly with synthetic chemical tailoring: The potential for 3-D genetically engineered micro/nanodevices (3-D GEMS). Int J Appl Ceram Technol 2005; 2: 317-326.

9. Chen Q, Chasiotis I, Chen C, et al. Nanoscale and effective mechanical behavior and fracture of silica nanocomposites. Compos Sci Technol 2008; 68: 3137-3144.

10. Wee KM, Rogers TN, Altan BS, et al. Engineering and medical applications of diatoms. J Nanosci Nanotechnol 2005; 5: 88-91.

11. Garcia AP, Sen D and Buehler MJ. Hierarchical silica nanostructures inspired by diatom algae yield superior deformability, toughness, and strength. Metall Mater Trans A-Phys Metall Mater Sci 2011; 42A: 3889-3897.

12. Dimas LS and Buehler MJ. Influence of geometry on mechanical properties of bio-inspired silica-based hierarchical materials. Bioinspir Biomim 2012; 7: 1-10.

13. Almqvist $\mathrm{N}$, Delamo $\mathrm{Y}$, Smith BL, et al. Micromechanical and structural properties of a pennate diatom investigated by atomic force microscopy. J Microsc-Oxford 2001; 202: 518-532.

14. Hamm CE, Merkel R, Springer O, et al. Architecture and material properties of diatom shells provide effective mechanical protection. Nature 2003; 421: 841-843.

15. Subhash G, Yao S, Bellinger B, et al. Investigation of mechanical properties of diatom frustules using nanoindentation. J Nanosci Nanotechnol 2005; 5: 50-56.
16. Li XW, Li XX and Wang GC. Surface modification of diatomite using polyaniline. Mater Chem Phys 2007; 102: $140-143$.

17. Zhang DY, Wang Y, Zhang WQ, et al. Enlargement of diatom frustules pores by hydrofluoric acid etching at room temperature. J Mater Sci 2011; 46: 5665-5671.

18. Tasdemirci A, Yuksel S, Karsu D, et al. Diatom frustulefilled epoxy: Experimental and numerical study of the quasi-static and high strain rate compression behavior. Mater Sci Eng A-Struct Mater Prop Microstruct Process 2008; 480: 373-382.

19. Gulturk EA, Guden M and Tasdemirci A. Calcined and natural frustules filled epoxy matrices: The effect of volume fraction on the tensile and compression behavior. Compos Part B-Eng 2013; 44: 491-500.

20. Elzea JM and Rice SB. TEM and X-ray diffraction evidence for cristobalite and tridymite stacking sequences in opal. Clays Clay Miner 1996; 44: 492-500.

21. Xiao WS, Peng WS, Wang GX, et al. Infrared spectroscopic study of changbaishan diatomite. Spectrosc Spectr Anal 2004; 24: 690-693.

22. Walh FM, Grim RE and Graf RB. Phase transformation in silica as examined by continuous diffraction. Am Miner 1961; 46: 196-208.

23. Aota JJ. Properties of heat treated diatomite. Vancouver, Canada: The University of British Columbia, 1985.

24. Goren R, Baykara T and Marsoglu M. A study on the purification of diatomite in hydrochloric acid. Scand $J$ Metall 2002; 31: 115-119. 